\title{
PELAKSANAAN SUPERVISI PENDIDIKAN \\ KEPALA SEKOLAH TERHADAP GURU
}

\section{ZIKRI KURNIA YORANDA}

17086092

EMAIL : zikri.kurniayoranda@gmail.com

\begin{abstract}
ABSTRAK
Kegiatan supervisi pendidikan sangat diperlukan oleh guru, karena bagi guru yangbekerja setiap hari di sekolah tidak ada pihak lain yang lebih dekat dan mengetahui dari dalamsegala kegiatannya, kecuali Kepala Sekolah. Guru merupakan salah satu faktor penenturendahnya mutu hasil pendidikan.Dalam rangka pelaksanaan program supervisi pendidikan maka harus mencakupsemua komponen yang terkait dan mempengaruhi terhadap keberhasilan program supervisipendidikan. Keberhasilan tersebut dilihat dari komponen perencanaan, implementasi dandampak dari program supervisi pendidikan.Kepala Sekolah dalam melaksanakan tugas dan tanggung jawabnya sebagai supervisorsecara efektif, maka Kepala Sekolah memiliki kompetensi yaitu kemanusiaan, manajerial, dan teknis. Kesemuanya merupakan satu kesatuan yang tidak dapat dipisahkan.
\end{abstract}

Kata Kunci: Supervisi Pendidikan, Kepala Sekolah, Guru 


\section{PENDAHULUAN}

Dewasa ini pendidikan untuk semua(education forall) akan menjadi dambaan setiap orang. Pendidikan seutuhnya(holisticeducation) akan banyak dibicarakan. Manusia akan sadar bahwa hidup ini membutuhkan belajar, untuk memperoleh pengalaman berarti menemukan kemanusiannya manusia. Orang yang belajar memerlukan bantuan dalam proses pembelajaran. Pembelajaran mendambakan orang yang mampu mendapat bantuan (assisting), mendapat support (supporting) dan diajak untuk tukar menukar (informasi). Tujuan pendidikan yang ingin dicapai yaitu mengembangkan kemampuan dan membentuk watak serta peradaban bangsa yang martabat dalam rangka mencerdaskan kehidupan bangsa, bertujuan untuk berkembangnya potensi peserta didik agar menjadi manusia yang beriman dan bertaqwa kepada Tuhan Yang Maha Esa, berakhlak mulia, sehat, berilmu, cakap, kreatif, mandiri, dan menjadi warga Negara yang demokratis serta tanggung jawab.

Untuk mencapai tujuan nasional tersebut perlu adanya peningkatan setiap jenis dan jenjang pendidikan. Untuk meningkatkan kualitas proses belajar mengajar guru mempunyai peranan yang sangat penting karena gurulah yang berfungsi secara langsung dalam proses belajar mengajar.

Kepala Sekolah sebagai pemimpin karena mempunyai tugas untuk memimpin staf (guruguru, pegawai dan pesuruh) untuk membina kerjasama yang harmonis antara anggota staf sehingga dapat membangkitkan semangat, serta motivasi kerja sebagai staf yang dipimpin serta meningkatkan suasana yang kondusif.

Kepala sekolah sebagai supervisor pendidikan mempunyai kewajiban membimbing dan membina guru atau staf lainnya. Pembinaan dan bimbingan guru akan berpengaruh besar terhadap kelangsungan dan kelancaran proses belajar mengajar.

Tugas kepala sekolah sebagai supervisor tersebut adalah memberi bimbingan, bantuan dan pengawasan dan penilaian pada masalah-maslah yang berhubungan dengan tehnis penyelenggara dan pengembangan pendidikan, pengajaran yang berupa perbaikan program pengajaran dan kegiatan-kegiatan pendidikan pengajaran untuk dapat menciptakan situasi belajar mengajar yang lebih baik. (Soetopo \& Wasty, 1998)

Meskipun dalam rancangan secara teoritik sudah ada pihak yang diharapkan dapat melakukan supervisi terhadap guru yaitu kepala sekolah namun belum dapat terlaksana dengan efektif. 
Dalam kenyataannya beberapa tahun terakhir ini terdapat kepala sekolah yang belum dapat menjalankan kegiatan supervisi dengan baik bahkan semakin berkurang keefektifannya. Ini diakibatkan beban kepala sekolah terlalu berat. Selain kepala sekolah guru juga mempunyai beban yang berat. Ini diakibatkan juga karena banyaknya bidang studi yang diajarkan oleh guru disekolah sehingga tampak akan sangat sulit mempertemukan keduanya. Oleh karena itu perlu dicari alternative pemecahannya pelaksanaan supervisi dapat berjalan efektif dan efesian.

\section{Landasan Teori}

Dalam buku pedoman pelaksanaan supervisi pendidikan disebutkan bahwa tujuan supervisi pendidikan adalah perbaikan dan perkembangan proses belajar mengajar secara total, ini berarti bahwa tujuan supervisi tidak hanya memperbaiki mutu guru, tetapi juga membina pertumbuhan profesi guru dalam arti luas termasuk di dalamnya pengadaan fasilitas-fasilitas, pelayanan, kepemimpinan dan pembinaan humanrelation yang baik kepada semua pihak yangterkait.

Tujuan dari supervisi klinis yaitu mengembangkan situasi belajar mengajar yang lebih efektif antara lain dengan:

1. Membantu guru agar dapat membantu murid-murid dalam proses belajar mengajar.

2. Membantu guru agar dapat melihat dengan jelas tujuan pendidikan.

3. Membimbing guru agar dapat mengefektifkan penggunaan sumber-sumber belajar.

4. Membnatu guru agar dapat mengevaluasi kemajuan belajar murid.

5. Membantu guru agar dapat menjalankan tugasnya dengan perasaan penuh tanggungjawab.

Tugas dan tanggungjawab Kepala Sekolah sebagai mengatur seluruh aspek kurikulum yang berlaku disekolah agar dapat berjalan dengan lancar dan dapat memberikan hasil yang sesuai dengan target yang telah ditentukan. Adapun aspek-aspek kurikulum tersebut, meliputi : a. Membantu guru-guru dalam merencanakan, melaksanakan dan menilai kegiatan program satuan pelajaran

b. Membantu guru dalam menyusun kegiatan belajar mengajar.

c. Membantu guru dalam menilai proses dan hasil belajar rmengajar

d. Membantu guru dalam menilai hasil belajar siswa

e. Membantu guru dalam menterjemahkan kurikulum kedalam pengajaran 
Neagley menulis 10 (sepuluh) tugas supervisor sebagai berikut:

a) Mengembangkan kurikulum

b) Mengorganisasi pengajaran

c) Menyiapkan staf pengajaran

d) Menyiapkan fasilitas belajar

e) Menyiapkanbahan-bahan pelajaran

f) Menyelenggarakan penataran-penataran guru

g) Memberikankonsultasi dan membina anggota staf pengajar

h) Mengkoordinasi layanan terhadap para siswa

i) Mengembangkan hubungan dengan masyarakat

j) Menilai pengajaran (Pidarta, 1997)

Definisi supervisi identik dengan pengawas memang tidaklah merupakan suatu kesalahan yang sangat besar, karena aktivitas mengawasi merupakan bagian kecil dari proses supervisi itu sendiri. Hanya perlu ditegaskan bahwa proses supervisi bukan hanya mengawasi suatu proses pekerjaan saja, tapi meliputi semua kegiatan yang berkaitan dengan pencapaian suatu tujuan, seperti mengkoordinir, membimbing, memotivasi, memimpin, mengoreksi, dan banyak lagi.

Supervisi berjalan ketika pertama kali guru direkrut sampai dengan ia dipensiunkan. Berawal dari proses orientasi pegawai baru, guru dikenalkan dengan segala bentuk informasi yang berkaitan dengan kelembagaan, pekerjaan, dan pengembangan diri. Ketika ia sudah melewati masa orientasi, masuk ketahapan bekerja yang sesungguhnya, proses supervisi terus dilakukan. Kinerja dan semua sepak-terjang guru dipantau, dinilai, dan tindaklanjuti, dan Dikembangkan sampai akhirnya ia sampai ke fase klimaks pekerjaan, pensiun.

Kualitas pembelajaran di Indonesia diindikasikan belum memenuhi kualitas yang diharapkan. Hal ini, berdampak pada prestasi belajar siswa yang belum menggembirakan terutama dibandingkan prestas belajar siswa di negara lainnya. Supervisi pendidikan memegang peranan penting dalam meningkatkan kualitas pembelajaran guru yang pada akhirnya menghasilkan prestasi belajar siswa yang tinggi. Peningkatan kualitas pembelajaran perlu dilakukan secara berkesinambungan seiring perkembangan ilmu pengetahuan, teknologi, serta sosial ekonomi dan budaya masyarakat. Pendekatan peningkatan keprofesionalan guru tersebut 
dapat dilakukan dengan teknik supervisi, menumbuhkan budaya organisasi pembelajar, dan kegiatan pelatihan. Dengan menggunakan pendekatan tersebut, dapat dilakukan peningkatan kinerja lembaga melalui peningkatan keprofesionalan guru secara berkelanjutan baik yang dilakukan seca ra perorangan maupun kelompok. (Sabandi, 2013) 


\section{PENUTUP}

Kepala sekolah sebagai pemimpin pendidikan mempunyai peran yang sangat besar dalam mengembangkan mutu pendidikan sekolah. Kedudukan kepala sekolah dalam hal ini begitu pentingnya, sehingga ada anggapan tentang "bagaimana" suatu sekolah sangat tergantung pada "bagaimana" kepala sekolahnya. Keberhasilan sekolah adalah keberhasilan kepala sekolah. Kepala Sekolah akan berhasil apabila mereka memahami keberadaan sekolah sebagai oiganisasi yang kompleks dan unik, serta mampu melaksanakan peran kepala sekolah sebagai seorang yang diberi amanat dan tanggung jawab untuk memimpin sekolah.

Ditinjau dari struktur organisasi di sekolah, kedudukan guru berada di bawah kepala sekolah. Kedudukan guru adalah sentral, artinya guru menduduki tempat inti dari fungsi sekolah. Guru melakukan tugas mengajar, mendidik, melatih dan membimbing. Kepala sekolah dalam upaya untuk memberdayakan guru, harus mampu menolong para guru dan staf administrasi untuk mencapai tujuan bersama yang telah ditetapkan, memberi kesempatan untuk mengemukakan gagasan, membangkitkan semangat kerja yang tinggi, menciptakan suasana kerja yang menyenangkan, aman dan penuh semangat.

Bantuan terhadap guru dalam melaksanakan tugas-tugas tersebut, dapat dilakukan melalui pelaksanaan supervisi pendidikan. Supervisi pendidikan memberikan tekanan pada proses pembentukan dan pengembangan kemampuan profesional guru, yang dimulai dengan mengadakan perbaikan dalam cara mengajar guru di kelas, dengan cara ini diharapkan siswa dapat belajar dengan baik, sehingga tujuan pengajaran dapat dicapai secara maksimal. Kepala sekolah sebagai supervisor, diharapkan dapat melaksanakan tugasnya dengan melakukan supervisi terhadap proses pembelajaran guru di kelas, dalam rangka meningkatkan kemampuan profesional guru yang tercermin pada kemampuan mengelola proses pembelajaran guru di kelas, yang meliputi: menguasai bahan pelajaran dalam pengertian menguasai bidang studi atau mata pelajaran yang dipegangnya, merencanakan program pembelajaran, melaksanakan dan memimpin/mengelola proses belajar, menilai kemajuan proses pembelajaran. 


\section{DAFTAR PUSTAKA}

Pidarta, M. (1997). Pemikiran tentang Supervisi Pendidikan. Surabaya: Sarana Press. Sabandi, A. (2013). SUPERVISI PENDIDIKAN UNTUK PENGEMBANGAN PROFESIONALITAS GURU BERKELANJUTAN. Pedagogi, Jurnal Ilmiah Ilmu Pendidikan, XIII(2), 1-9. Retrieved from http://ejournal.unp.ac.id/index.php/pedagogi/article/view/4275

Soetopo, H., \& Wasty. (1998). Kepemimpinan Yang Efektif. Yogyakarta: Gadjah Mada University. 